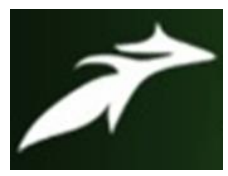

PALUKURI SINDHUJA et al, International Journal of Advances in Agricultural Science and Technology,

Vol.8 Issue.9, September-2021, pg. 114-125

ISSN: 2348-1358

Impact Factor: 6.057

NAAS Rating: 3.77

\title{
EFFECTIVENESS OF AGRICULTURAL PROGRAMMES ON TELEVISION AS PERCEIVED BY TELEVIEWING FARMERS IN CHITTOOR DISTRICT OF ANDHRA PRADESH
}

\author{
PALUKURI SINDHUJA ${ }^{1}$; JAHANARA ${ }^{2}$; SYED H MAZHAR ${ }^{3}$ \\ ${ }^{\mathbf{1}}$ Research Scholar, Department of Agricultural Extension and Communication, SHUATS, Allahabad, Uttar Pradesh, India \\ ${ }^{2}$ Professor and Head, Department of Agricultural Extension and Communication, SHUATS, Allahabad, Uttar Pradesh, India \\ ${ }^{3}$ Associate Professor, Department of Agricultural Extension and Communication, SHUATS, Allahabad, Uttar Pradesh, India \\ DOI: 10.47856/ijaast.2021.v08i9.013
}

\begin{abstract}
The present study was undertaken with the main objective of assessing the effectiveness of agricultural programmes of different channels as perceived by the televiewing farmers. Before and After research design was followed in the present investigation. The study was conducted in Tirupathi mandal, Chittoor district which were selected purposively. The data were collected randomly by talking personally interview of 120 televiewers. The data was collected by personal interview method through structured interview schedule. Majority of the respondents were middle aged, had medium level of education, medium farming experience, medium land holding, medium level of extension contact, mass media exposure, economic orientation, achievement motivation and innovativeness. Majority of the respondents had perception of televiewing farmers of different channels with respect to components of effectiveness, namely understandability, usefulness, demonstration mode of presentation, entertainment and relevancy of pictures. "Time duration is not sufficient", "Telecast time is not convenient", "Telecast programmes are useful to the farming community" and "Telecast programme are drawing attention of the farmers to bring awareness on new technology" were the major reactions of the respondents. Telecast time need to be changed from 6:00am-7.00am and 7.00pm-9.00pm, all programmes should be telecasted should be telecasted daily, information on the schedule of the topics to be telecasted in the telecasted in the consecutive week should be advertised at the starting of the week, separate television channel is required to telecast agriculture related activities.
\end{abstract}

Keywords: Perceived Effectiveness, Farm information, Agriculture, Mass media, Television.

\section{INTRODUCTION}

New technologies for increasing agricultural production are now becoming available at a much faster rate. But the mechanism for transferring them to the uneducated and small producers in an effective manner does not exist. There is an urgent need for an effective communication network. Effective communication of farm information to the farmers is key to socio-economic transformation of our nation, particularly when the bulk of the population lives on farming. But in India, where farmers live in less accessible and isolated villages both on plains and hills, such 


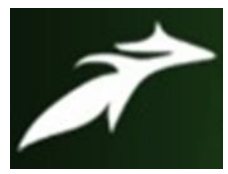

PALUKURI SINDHUJA et al, International Journal of Advances in Agricultural Science and Technology, Vol.8 Issue.9, September-2021, pg. 114-125

ISSN: 2348-1358

Impact Factor: 6.057

NAAS Rating: 3.77

as effective communication is all the more difficult (Chudhury et.al.2017). The function of the communication in the context of agricultural development is to inform, educate and motivate the farmers to accept new ideas and agricultural practices in order to increase the production per unit of land. In this situation, mass media can be hopefully expected to cater the need to a great extent. It is not knowledge that is needed, but an approach which will be able to supply the right knowledge and tools to the right people at the right time. The present age has been rightly termed as an "Information age"(Alam and Haque 2014). People want adequate and authentic information within shortest possible time. Of the mass media, no doubt, radio and television are powerful. Out of these, television is more powerful medium of communication as it performs both the auditory and visual functions, simultaneously. Television has specific advantages over other mass media viz., radio, newspaper etc. It overcomes the barriers put up by illiteracy and provides speedy mass communication. It is a multimedia system predominated by the visual medium. Television reaches both the illiterate and literate audience. Thus, it is superior to the print media. It has advantages over radio because of its visual content which provides a great help in the trial phase of adoption process. It is most effective medium of education as it combines both visual presentation and sound. Television has tremendous potential and has become a world-wide phenomenon. Television plays an important role in the field of agriculture development by informing the farmers about new techniques in agriculture. As a principle of 'seeing is believing', farmers believe in television(Ventaka krishnaji and Gopikrishna 2019). The first regular public transmission of television started in England in 1936. Now, television has become a world-wide phenomenon. An experimental television service was introduced in India with inauguration of Delhi Kendra with UNESCO grants on September 15, 1959. Rural development in India mainly depends upon the development of agriculture, because 70 per cent of the populations rely on agriculture for livelihood. Knowing this, the first programme on agriculture and rural development was started on Delhi Doordarshan Kendra on January 26, 1967under the name Krishi Darshan.

In Andhra Pradesh, ETV-Telugu was launched on $9^{\text {th }}$ July, 2000. Right from the day the first regional channel was launched in June, 1996, ETV has been offering an exclusive half an hour daily programme on agriculture and allied sectors under the name 'Annadata'. The programme is telecast every day between 6.30 a.m. to 7.00 a.m. Over the years 'Annadata' has become an inseparable part of farmers' life. DD Saptagiri (Telugu) is a state-owned television channel telecasting in the Telugu language from a studio at Doordarshan Kendra Vijayawada, Andhra Pradesh, India. DD Saptagiri was launched on 27 september, 2014. Right from the first regional channel was launched in $2^{\text {nd }}$ April, 2003. The agriculture programme was named as 


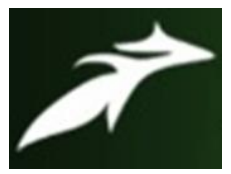

PALUKURI SINDHUJA et al, International Journal of Advances in Agricultural Science and Technology, Vol.8 Issue.9, September-2021, pg. 114-125

ISSN: 2348-1358

Impact Factor: 6.057

NAAS Rating: 3.77

'pasidipantalu'. The programme is telecast every day between 6.00 p.m. to 7.00 p.m. DD Yadagiri is a state-owned Telugu language television channel operated by India's national broadcaster Doordarshan. It was launched in $23^{\text {rd }}$ October, 1977 and Doordarshan Kendra Regional Network in Telugu took on a new identity of DD saptagiri, on $2^{\text {nd }}$ April, 2003. The progamme named as 'Rythu nestam'. The programme is telecast every day between 6.00 p.m to $7.00 \mathrm{pm}$. The television era in India began modestly on September 15, 1959 which was started by the All India Radio, Delhi and programmes were telecasted twice a week for duration of one hour each day. In Andhra Pradesh farm telecast programmes were started as Grama darshini, Polampanulu, Karshaka lokam and Pantaseemalu in 1972. Later the private channels like ETV and Teja were started telecasting the livestock farmers oriented programmes like Annadata and Rythu mitra (which includes a five minute Farm Bulletin "Vyavasaya Varthalu") five days in week i.e. from Monday to Friday during the year 1995 and 2001, respectively.

List of different television channels telecasting agriculture related programmes in Telugu are as follows:

\begin{tabular}{|c|c|c|c|c|}
\hline S.No & $\begin{array}{l}\text { Name of the TV } \\
\text { channel }\end{array}$ & Name of the programme & Time & Frequency \\
\hline 1. & ETV Telugu & Annadata & 6.30 a.m-7.00 a.m & Daily \\
\hline 2. & $\begin{array}{l}\text { ETV AP \& } \\
\text { Telangana }\end{array}$ & Annadata & 6.30 p.m-7.00 p.m & Daily \\
\hline 3. & ETV Telugu & Jai kisan & 6.50 a.m- 7.00 a.m & Daily \\
\hline 4. & $\begin{array}{l}\text { Doordharshan } \\
\text { Sapthagiri }\end{array}$ & Pasidipantalu & 6.00 p.m-7.00 p.m & Daily \\
\hline 5. & $\begin{array}{l}\text { Doordharshan } \\
\text { Yadagiri }\end{array}$ & Rythu nestam & 6.00 p.m-7.00 p.m & Daily \\
\hline 6. & Saakshi TV & Sagu badi & 4.30 p.m- 5.00 p.m & Daily \\
\hline 7. & $10 \mathrm{TV}$ & Matti manishi & 6.30 a.m-7.00 a.m & Daily \\
\hline 8. & T news & Chenu chelaka & 6.30 p.m-7.00 p.m & Daily \\
\hline
\end{tabular}

\section{RESEARCH METHODOLOGY}

This section describes the approaches and methods employed for data collection and analysis. The first sub-section of this chapter presents the description of the study area. Then the details of methodology used to conduct the overall study were discussed in subsequent sub-sections. The before-and-after design offers better evidence about intervention effectiveness than the other 


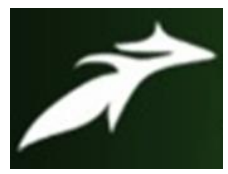

PALUKURI SINDHUJA et al, International Journal of Advances in Agricultural Science and Technology, Vol.8 Issue.9, September-2021, pg. 114-125

ISSN: 2348-1358

Impact Factor: 6.057

NAAS Rating: 3.77

non-experimental designs. The before- and- after design is most useful in demonstrating the immediate impacts of short-term programs. It is less useful for evaluating longer term interventions. This is because over the course of a longer period of time, more circumstances can arise that may obscure the effects of an interventions. These circumstances are collectively called threats to internal validity. The state of ANDHRA PRADESH in CHITTOOR DISTRICT was purposively selected for the study. Chittoor district is one of the four districts in the Rayalaseema region of the Indian state of Andhra Pradesh. The district is divided into 3 revenue divisions viz., Chittoor, Tirupathi and Madanapalle. Literacy average rate of Chittoor district is 71.53 percent. "Telecast programmes are drawing attention of the farmers to bring awareness on new technology". Chittoor district of Andhra Pradesh is selected purposively for the present study. The researcher is well versed with the conditions of the district, as the researcher belongs to the same district. Agriculture development activities were under taken extensively in the district. There are total 66 mandals in Chittoor district of Andhra Pradesh, out of which Tirupathi mandal will be selected purposively on the basis of maximum televiewing farmers. The list of villages under selected tirupathi mandal was obtained from district gazette. From the list, villages having the good facility of Television viewing and also good telecast facility of all channels that telecasts the Agricultural programmes were identified. Among such villages were selected at random from tirupathi mandal viz., peruru, pathakavala, gollapalli, perumalpalle, cheriopalle, Upparapalle, pudipatla, Mallavaram, satharubailu. Thus a total of nine villages from tirupathi mandal of chittoor district were selected for the present investigation. The list of farm televiewers, who were viewing Agricultural programmes was prepared separately for each selected villages and by adopting quota sampling method from each village thirteen to fourteen farmers were selected at random, thus a total of 120 respondents were selected from nine villages.

\section{RESULTS AND DISCUSSION}

Table-1: To assess the socio-economic profile of the farmers.

\begin{tabular}{|c|c|c|c|c|}
\hline S.No & \multicolumn{2}{|c|}{ Socio-economic profile of the farmers } & Frequency & Percentage \\
\hline \multirow{2}{*}{1.} & \multirow{2}{*}{ Gender } & Male & 84 & 70 \\
\cline { 3 - 4 } & & Female & 36 & 30 \\
\hline \multirow{2}{*}{2.} & \multirow{2}{*}{ Age } & Young(below 35 years) & 17 & 14.17 \\
\cline { 3 - 4 } & & Middle(b/w 36-50years) & 62 & 51.66 \\
\cline { 3 - 4 } & & Old(above 51 years) & 41 & 34.17 \\
\hline \multirow{2}{*}{3.} & Caste & OC & 48 & 40 \\
\cline { 3 - 4 } & & OBC & 55 & 45.83 \\
\hline
\end{tabular}




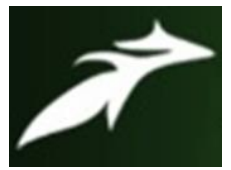

PALUKURI SINDHUJA et al, International Journal of Advances in Agricultural Science and Technology,

Vol.8 Issue.9, September-2021, pg. 114-125

ISSN: 2348-1358

Impact Factor: 6.057

NAAS Rating: 3.77

\begin{tabular}{|c|c|c|c|c|}
\hline & & SC/ST & 17 & 14.17 \\
\hline \multirow[t]{3}{*}{4.} & \multirow[t]{3}{*}{ Education } & Illiterate \& Primary & 27 & 22.5 \\
\hline & & Upper Primary \& Secondary & 58 & 48.33 \\
\hline & & $\begin{array}{c}\text { Higher } \\
\text { Secondary,Graduate\&above }\end{array}$ & 35 & 29.17 \\
\hline \multirow[t]{3}{*}{5.} & \multirow{3}{*}{$\begin{array}{l}\text { Occupation of } \\
\text { family }\end{array}$} & Agriculture & 82 & 68.33 \\
\hline & & Agriculture+Labour & 10 & 8.34 \\
\hline & & Agriculture+Other & 28 & 23.33 \\
\hline \multirow[t]{2}{*}{6.} & \multirow[t]{2}{*}{ Family type } & Nuclear & 99 & 82.5 \\
\hline & & Joint & 21 & 17.5 \\
\hline \multirow[t]{3}{*}{7.} & \multirow[t]{3}{*}{ Family size } & Small(1-3) & 20 & 16.7 \\
\hline & & Medium(4-6) & 82 & 68.3 \\
\hline & & Large $(>7)$ & 18 & 15 \\
\hline \multirow[t]{3}{*}{8.} & \multirow[t]{3}{*}{ Type of House } & Mud house & 9 & 7.5 \\
\hline & & Semi cemented & 53 & 44.17 \\
\hline & & Cemented & 58 & 48.33 \\
\hline \multirow[t]{3}{*}{9.} & \multirow[t]{3}{*}{ Annual Income } & Upto 1 lak & 26 & 21.67 \\
\hline & & 1-3 lak & 70 & 58.33 \\
\hline & & Above 3 lak & 24 & 20 \\
\hline \multirow[t]{3}{*}{10.} & \multirow[t]{3}{*}{ Land holding } & $1-3$ acre & 49 & 40.83 \\
\hline & & 4-6 acre & 47 & 39.17 \\
\hline & & Above 7 acre & 24 & 20 \\
\hline \multirow[t]{3}{*}{11.} & \multirow[t]{3}{*}{ Farming experience } & $1-20$ years & 35 & 29.17 \\
\hline & & $21-30$ years & 51 & 42.5 \\
\hline & & Above 31 years & 34 & 28.33 \\
\hline \multirow[t]{3}{*}{12.} & \multirow[t]{3}{*}{ Material Possession } & Low & 12 & 10 \\
\hline & & Medium & 85 & 70.83 \\
\hline & & High & 23 & 19.17 \\
\hline \multirow[t]{3}{*}{13.} & \multirow[t]{3}{*}{ Extension contact } & Low & 32 & 26.67 \\
\hline & & Medium & 48 & 40 \\
\hline & & High & 40 & 33.33 \\
\hline \multirow[t]{3}{*}{14.} & \multirow{3}{*}{$\begin{array}{l}\text { Mass media } \\
\text { exposure }\end{array}$} & Low & 12 & 10 \\
\hline & & Medium & 71 & 59.17 \\
\hline & & High & 37 & 30.83 \\
\hline \multirow[t]{3}{*}{15.} & \multirow[t]{3}{*}{ Innovativeness } & Low & 34 & 28.33 \\
\hline & & Medium & 53 & 44.17 \\
\hline & & High & 33 & 27.5 \\
\hline
\end{tabular}




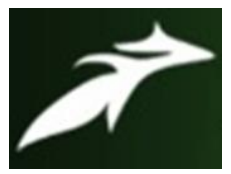

PALUKURI SINDHUJA et al, International Journal of Advances in Agricultural Science and Technology, Vol.8 Issue.9, September-2021, pg. 114-125

ISSN: 2348-1358

Impact Factor: 6.057

NAAS Rating: 3.77

\begin{tabular}{|c|c|c|c|c|}
\hline \multirow[t]{3}{*}{16.} & \multirow{3}{*}{$\begin{array}{l}\text { Economic } \\
\text { orientation }\end{array}$} & Low & 13 & 10.83 \\
\hline & & Medium & 38 & 31.67 \\
\hline & & High & 69 & 57.5 \\
\hline \multirow[t]{3}{*}{17.} & \multirow{3}{*}{$\begin{array}{l}\text { Scientific } \\
\text { Orientation }\end{array}$} & Low & 17 & 14.17 \\
\hline & & Medium & 67 & 55.83 \\
\hline & & High & 36 & 30 \\
\hline \multirow[t]{3}{*}{18.} & \multirow{3}{*}{$\begin{array}{c}\text { Achievement } \\
\text { motivation }\end{array}$} & Low & 28 & 23.33 \\
\hline & & Medium & 53 & 44.17 \\
\hline & & High & 39 & 32.5 \\
\hline
\end{tabular}

\section{Gender:}

The results indicated that majorities $(70 \%)$ of the farm televiewers were men and women viewers represented $30 \%$ of the study.

2. Age:

The results indicated that majorities $(51.66 \%)$ of the respondents were middle aged followed by old $(34.17 \%)$ and young $(14.17 \%)$ categories, respectively.

3. Caste:

The results indicated that $45.83 \%$ of the respondents belonged to OBC category followed by $40 \%$ of OC, $14.17 \%$ of SC/ ST categories respectively.

\section{Education:}

It is evident that $48.33 \%$ of the respondents were Upper Primary \& Secondary followed Higher Secondary, Graduate and above $(29.17 \%)$ and Illiterate and primary $(22.5 \%)$.

\section{Occupation of family:}

It can be reported that majority $68.33 \%$ of the respondents had Agriculture as main occupation, $23.33 \%$ of the respondents had Agriculture+Labour, $8.34 \%$ of the respondents had Agriculture+Other.

\section{Family type:}

It could be reported that majority $82.5 \%$ of the respondents belonged to the nuclear family and $17.5 \%$ of the respondents belonged to the joint family.

\section{Family size:}

A perusal revealed that majority $68.3 \%$ of the respondents had medium family size followed by $16.7 \%$ with small, $15 \%$ with large respondents of family size. 


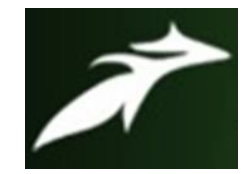

PALUKURI SINDHUJA et al, International Journal of Advances in Agricultural Science and Technology, Vol.8 Issue.9, September-2021, pg. 114-125

ISSN: $2348-1358$

Impact Factor: 6.057

NAAS Rating: 3.77

\section{Type of House:}

It could be reported that majority $48.33 \%$ of the respondents had cemented house followed by $44.17 \%$ with semi cemented house and $7.5 \%$ of the respondents belongs to the Mud house.

\section{Annual Income:}

The results indicate that majority $58.33 \%$ of the respondents belonged to 1-3 lakh (medium) income group followed by $21.67 \%$ with upto 1 lakh (Low) and $20 \%$ of the respondents with above 3 lakh (High) income group, respectively.

\section{Land holding:}

It could majority $40.83 \%$ of the respondents categorized under 1-3 acre sized land holding followed by $39.17 \%$ of $4-6$ acre, $20 \%$ of $>7$ acre sized land holding categories.

\section{Farming experience:}

Results indicate that majority (42.5\%) of the respondents were having 21-30 years farming experience followed by 1-20years (29.17\%), >31 years $(28.33 \%)$ of farming experience.

\section{Material Possession:}

From reported that majority $(70.83 \%)$ of the respondents had medium material possession followed by high(19.17\%) and low (10\%) material possession.

\section{Extension contact:}

It could been seen $40 \%$ of the respondents had Medium level of extension contact followed by $33.33 \%$ of High level and $26.67 \%$ of the respondents had Low level of extension contact, respectively.

\section{Mass media exposure:}

Findings reveals that $59.17 \%$ of the respondents had medium level of mass media exposure followed by high $(30.83 \%)$ and low (10\%) levels of mass media exposure by the respondents.

\section{Innovativeness:}

The results indicate that majority $(44.17 \%)$ of the respondents possessed medium level of innovativeness followed by $\operatorname{Low}(28.33 \%)$ and High (27.5\%) levels of innovativeness among the respondents.

\section{Economic orientation:}

Results indicate that majority $(57.5 \%)$ of the respondents had High level of economic orientation followed by $31.67 \%$ with medium level and $10.83 \%$ of the respondents with low economic orientation, respectively. 


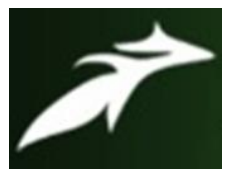

PALUKURI SINDHUJA et al, International Journal of Advances in Agricultural Science and Technology, Vol.8 Issue.9, September-2021, pg. 114-125

ISSN: 2348-1358

Impact Factor: 6.057

NAAS Rating: 3.77

\section{Scientific orientation:}

The findings revealed that majority $(55.83 \%)$ of the respondents had medium level of scientific orientation followed by $30 \%$ with high level and $14.17 \%$ with low level of scientific orientation, respectively.

\section{Achievement orientation:}

It indicate that the most of the respondents (44.17\%) had medium level of achievement motivation followed by High(32.5\%) and Low(23.33\%) levels of achievement motivation among the respondents.

Table-2: EFFECTIVENESS OF AGRICULTURAL PROGRAMMES ON TELEVISION AS PERCEIVED BY TELEVIEWING FARMERS.

\begin{tabular}{|c|c|c|c|c|c|c|c|}
\hline \multirow[t]{2}{*}{ S.No } & \multirow[t]{2}{*}{ Effectiveness } & \multicolumn{2}{|c|}{$\mathbf{A}$} & \multicolumn{2}{|c|}{ UD } & \multicolumn{2}{|c|}{ DA } \\
\hline & & $\mathbf{F}$ & P\% & $\mathbf{F}$ & P\% & $\mathbf{F}$ & P\% \\
\hline 1. & $\begin{array}{l}\text { Agricultural information telecast on } \\
\text { TV programmes are more effective to } \\
\text { their farmer. }\end{array}$ & 107 & 89.17 & 13 & 10.83 & - & - \\
\hline 2. & $\begin{array}{l}\text { Information providing through } \\
\text { agricultural programmes on } \\
\text { Television is useful to farmers. }\end{array}$ & 101 & 84.17 & 19 & 15.83 & - & - \\
\hline 3. & $\begin{array}{l}\text { Farmers are gaining the knowledge } \\
\text { through agricultural programmes by } \\
\text { the help of television. }\end{array}$ & 91 & 75.83 & 27 & 22.5 & 2 & 1.67 \\
\hline 4. & $\begin{array}{l}\text { Presentation through Demonstration, } \\
\text { Discussion, Interview, Dramatic of } \\
\text { agricultural programme on television } \\
\text { to the farmers are very effective. }\end{array}$ & 67 & 55.83 & 48 & 40 & 5 & 4.17 \\
\hline 5. & $\begin{array}{l}\text { Information through agricultural } \\
\text { programme on television to the } \\
\text { farmers covered each and every area. }\end{array}$ & 69 & 57.5 & 46 & 38.33 & 5 & 4.17 \\
\hline 6. & $\begin{array}{l}\text { The language used in agricultural } \\
\text { programmes on television is mostly } \\
\text { effective to the farmers. }\end{array}$ & 59 & 49.17 & 54 & 45 & 7 & 5.83 \\
\hline 7. & $\begin{array}{l}\text { Agricultural programmes on } \\
\text { television is entertaining to farmers. }\end{array}$ & 57 & 47.5 & 56 & 46.67 & 7 & 5.83 \\
\hline
\end{tabular}




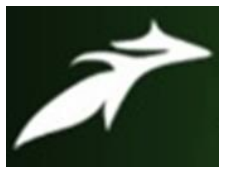

PALUKURI SINDHUJA et al, International Journal of Advances in Agricultural Science and Technology, Vol.8 Issue.9, September-2021, pg. 114-125

ISSN: 2348-1358

Impact Factor: 6.057

NAAS Rating: 3.77

\begin{tabular}{|c|l|c|c|c|c|c|c|}
\hline 8. & $\begin{array}{l}\text { Agricultural programmes on } \\
\text { television as per season. }\end{array}$ & 88 & 73.33 & 28 & 23.33 & 4 & 3.33 \\
\hline 9. & $\begin{array}{l}\text { Agricultural programme on television } \\
\text { is adequate to farmers. }\end{array}$ & 64 & 53.33 & 51 & 42.5 & 5 & 4.17 \\
\hline 10. & $\begin{array}{l}\text { Information given through agricultural } \\
\text { programme on television is accurate. }\end{array}$ & 51 & 42.5 & 60 & 50 & 9 & 7.5 \\
\hline 11. & $\begin{array}{l}\text { The speed of presentation of } \\
\text { information on television is easy to } \\
\text { understand to the farmers. }\end{array}$ & 68 & 56.67 & 44 & 36.67 & 8 & 6.67 \\
\hline 12. & $\begin{array}{l}\text { Agriculture programmes on television } \\
\text { are most effective treatment for the } \\
\text { farmers. }\end{array}$ & 64 & 53.33 & 43 & 35.83 & 13 & 10.84 \\
\hline 13. & $\begin{array}{l}\text { Effectiveness of television for } \\
\text { increasing agricultural income among } \\
\text { the farmers. }\end{array}$ & 12 & 10 & 70 & 58.33 & 38 & 31.67 \\
\hline 14. & $\begin{array}{l}\text { Television is the medium to } \\
\text { disseminate agriculture related } \\
\text { information to the farmers. }\end{array}$ & 22 & 18.33 & 65 & 54.17 & 33 & 27.5 \\
\hline
\end{tabular}

It is revealed from Table-2 effectiveness of televiewing farmers expressed that $89.17 \%$ of farmers are agree with agricultural information telecast on TV programmes are more effective to the farmers, $84.17 \%$ of farmers agree with information providing through agricultural programmes on television is useful to farmers, $75.83 \%$ of farmers agree with farmers are gaining the knowledge through agricultural programmes by the help of television, $73.33 \%$ of farmers agree with agricultural programmes on television were as per season, $58.33 \%$ of farmers undecided with effectiveness of television for increasing agricultural income among the farmers, $57.5 \%$ of farmers agree with information through agricultural programmes on television to the farmers covered each and every area, $56.67 \%$ of farmers agree with the speed of presentation of information on television is easy to understand to the farmers, $54.17 \%$ of farmers undecided with television is the medium to disseminate agriculture related information to the farmers, $53.33 \%$ of farmers agree with agricultural programme on television is adequate to farmers, $53.33 \%$ of farmers agree with agriculture programmes on television are most effective treatment for the farmers, $50 \%$ of farmers undecided with information given through agricultural programme on television is accurate, $49.17 \%$ of farmers agree with the language used in agricultural 


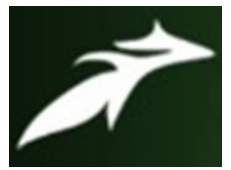

PALUKURI SINDHUJA et al, International Journal of Advances in Agricultural Science and Technology, Vol.8 Issue.9, September-2021, pg. 114-125

ISSN: 2348-1358 Impact Factor: 6.057 NAAS Rating: 3.77

programmes on television is mostly effective to the farmers, $46.67 \%$ of farmers undecided with agricultural programmes on television is entertaining to farmers.

Table- 3: Distribution of respondents according to their perceived effectiveness

\begin{tabular}{|c|c|c|c|}
\hline S.No & Perceived Effectiveness & Frequency & Percentage \\
\hline 1. & Low & 17 & 14.17 \\
\hline 2. & Medium & 46 & 38.33 \\
\hline 3. & High & 57 & 47.5 \\
\hline & Total & 120 & 100.00 \\
\hline
\end{tabular}

An examination of Table-3, indicate that the most of the respondents (47.5\%) had high level of perceived effectiveness followed by medium $(38.33 \%)$ and low $(14.17 \%)$ levels of perceived effectiveness among the respondents.

Table-4: Relationship between independent variables and Perceived Effectiveness of the respondents, $n=120$.

\begin{tabular}{|c|c|c|}
\hline S.No & Characteristics & 'r' value \\
\hline $\mathbf{1 .}$ & Age & $0.728^{* *}$ \\
\hline $\mathbf{2 .}$ & Education & $0.484^{* *}$ \\
\hline $\mathbf{3 .}$ & Annual Income & $0.214^{*}$ \\
\hline $\mathbf{4 .}$ & Farming Experience & $0.200^{* *}$ \\
\hline $\mathbf{5 .}$ & Extension Contact & $0.701^{* *}$ \\
\hline $\mathbf{6 .}$ & Mass media exposure & $0.636^{* *}$ \\
\hline $\mathbf{7 .}$ & Innovativeness & $0.208^{*}$ \\
\hline $\mathbf{8 .}$ & Economic Orientation & $0.950^{* *}$ \\
\hline $\mathbf{9 .}$ & Scientific Orientation & $0.597^{* *}$ \\
\hline $\mathbf{1 0 .}$ & Acheivement Orientation & $0.650^{* *}$ \\
\hline
\end{tabular}

* : Significant at 0.05 level of probability

** : Significant at 0.01 level of probability 


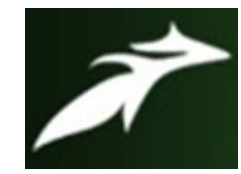

PALUKURI SINDHUJA et al, International Journal of Advances in Agricultural Science and Technology, Vol.8 Issue.9, September-2021, pg. 114-125

ISSN: 2348-1358

Impact Factor: 6.057

NAAS Rating: 3.77

\section{NS: Non- Significant}

The above Table- 4 indicates that, the relationship between Independent variables and perceived effectiveness of respondents by applying Karl Pearson's co-efficient of correlation. $1^{\text {st }}$ of all the co-efficient of co-relation between perceived effectiveness of respondents of agricultural programmes and their socio-economic profile was calculated. After that calculated values were compared with tabulated co-efficient of co-relation value. Then this results which clearly indicates that selected characteristics of respondents i.e. Age, Education, Farming experience, Extension contact, Mass media exposure, Economic orientation, Scientific orientation, Achievement orientation had positive and highly significant relationship at 0.01 level of probability with perceived effectiveness of the respondents towards agricultural programmes on television Whereas, Annual income and Innovativeness had positive significant relationship at 0.05 level of probability with perceived effectiveness of the respondents towards agricultural programmes on television.

\section{CONCLUSION:}

Television plays a vital role in communication of farm technology to the farmers. However, no much attempts have been made in the past to know how far the farm telecasts of a private and government channels are effective as perceived by televiewing farmers, and the determinants of perceived effectiveness. The absence of such evidences limits the scope for a critical discussion on effectiveness of different components of the agricultural programmes on television and ways to improve them. Considering the age, education, farming experience, land holding and mass media exposure of the televiewing farmers there is a scope and need of appointing more extension personnel to take necessary steps to bring the medium level to high level. The findings pertaining to component wise perceived effectiveness of the agri telecast proved that by and large, the televiewers were satisfied with the understandability, usefulness, gain in knowledge, new information, mode of presentation, entertainment, coverage of information, speed of presentation, relevancy of picture, quality of picture and sound of farm telecasts on television. 


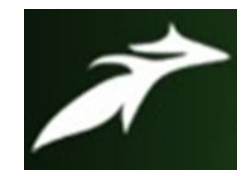

PALUKURI SINDHUJA et al, International Journal of Advances in Agricultural Science and Technology,

Vol.8 Issue.9, September-2021, pg. 114-125

ISSN: 2348-1358

Impact Factor: 6.057

NAAS Rating: 3.77

\section{REFERENCES}

[1]. Alam, Mohammed Khalid, Haque, Md. Armanul. (2014). Contribution of Television Channels in Disseminating Agricultural Information for the Agricultural Development of Bangladesh: A Case Study. Library philosophy and practice (e-journal),Paper 1048.

[2]. Chhachhar A R, Md Salleh Hassan, Siti Zobidah Omar, Badaruddin Soomro 2012a The role of television in dissemination of agriculture information among farmers Journal of Applied Environmental and Biological Science 2(11): 586-591.

[3]. Devaraj and Ravichandran P 2014 A Study on the Role of Information and mass-media Communication technology among farming community of Mandya district Karnataka. State Journal of Advances in Library and Information Science 3(1): 43-46.

[4]. F H Chudhury, M R Amin, M M Adhikary, M A Islam and M Rokonuzzaman 2017. Effectiveness of Agriculture related Television Programmes for Disseminating Agricultural information perceived by the farmers of Bangladesh. Journal of Agroecology and Natural Resource Management, 4(1): 101-104.

[5]. Gababolokwe,k. and Hulela, k. 2014 Farmer's Perceptions Regarding the use of Botswana's Tsa Temo Thuo Television Programme. Asian Journal of Agriculture and Rural Development 4(7): 381-391.

[6]. Mohammad Reza Nazari and Md Salleh Bin Hj Hassan 2011 The role of television in the enhancement of farmers agricultural knowledge. African Journal of Agricultural Research 6(4): 931-936.

[7]. M. Venkata Krishnayi and T. Gopikrishna 2019. Profile Characterstics of Televiewing farmers of Andhra Pradesh, India. International Journal of Current Microbiology and Applied Sciences, 8(10): 2452-2459.

[8]. Olajide B.R., Adenyi, A. and Ladigbolu, T.A. 2015. Viewer's perception of Oju-oja agricultural marketing television programme of Ekiti State broadcasting Service, Ekiti state, Nigeria. International Journal of Agricultural Economic \& Rural Development, 7(1): 1-130.

[9]. Periyasamy Raviswamy, Siva balan Kulandaivel Chellappna and Nandakumar Subramaniam 2017. Television for Effective Dissemination of Farm Information to Banana Growers: A Study from Tamilnadu. Progressive Research- An International Journal, 12(1): 1146-1149.

[10]. Rahul Kumar Singh 2015. Study on Socio-economic profile of Television Viewers in Wazirganj, Block of Gonda, District(U.P.). Annuals of plant and soil Research, 17: 138-141.

[11].Salleh Hassan Md., Hayrol Mohamed Shaffril, Bahaman Abu Samah, Muhamad Shamshahkat Ali, Nor Sabila Ramli and Zoheir Sabaghpour Azarian 2012 The credibility of television in disseminating agricultural information to farmers in Malaysia. Asian Social Science 8(12): 133-139.

[12].Suzan Khan, M Hammadur Rahman and Mohammed Nasir Uddin 2017. Effectiveness of selected Mass Media in Agricultural Technology Transfer to the Farmers of Bangladesh. Research Article in Agriculture, Livestock and Fisheries, 4(1): 07-13. 